\title{
Genetic Transformation Studies on Avocado Cultivar “Hass” (Persea americana)
}

\author{
Muhammad F. Ahmed ${ }^{1}$, Arumugam S. Kantharajah ${ }^{2 *}$, Paul Holford ${ }^{1}$ \\ ${ }^{1}$ University of Western Sydney, South Penrith DC, Australia; ${ }^{2}$ Department of Agricultural Sciences, American University of Beirut, \\ Beirut, Lebanon. \\ Email: ${ }^{* a k 105 @ a u b . e d u . l b ~}$
}

Received March 16 ${ }^{\text {th }}, 2012$; revised April 10 ${ }^{\text {th }}, 2012$; accepted April 26 $6^{\text {th }}, 2012$

\begin{abstract}
The use of traditional breeding for improvement of avocado cultivars is time consuming, hence other methods such as genetic transformation by Agrobacterium is indispensable to adopt. The strain GV3850/pBI121gave best transformation outcome compared to five other binary vectors (AGL1/pCGP904; AGL1/pBI121; GV3850/pCGP904; LBA4404/pCGP904 and LBA4404/pBI121) under different $\mathrm{pH}$ and acetosyringone concentrations. The optimal condition for reliable transformation was by using $200 \mu \mathrm{M}$ acetosyringone and a pH of 5.2. Transformed embryonic shoots co-cultivated with GV3850/pBI121 were tested using the histochemical x-gluc assay. Further analysis was conducted by polymerase chain reaction using specific primers for the reporter gene (GUS).
\end{abstract}

Keywords: Avocado; Persea; Binary Vectors; GUS Reporter

\section{Introduction}

The avocado is a major horticultural crop in tropical parts of the world. Although avocado has a high economic and nutritional importance, there are genetic problems associated with its production. The successful incorporation of transfer-DNA (T-DNA) from wild-type strains of Agrobacterium tumefaciens to avocado tissues has been observed. However the wild-type Ti-plasmids are not suitable as gene vectors as they produce disorganized growth of recipient plant cells owing to the effects of the oncogenes in the T-DNA. Consequently, such tumour cells have proven recalcitrant to attempts to induce regeneration into plantlets or normal tissues. In order to regenerate plants effectively, the T-DNA has to be disarmed. This is achieved by deleting all of its oncogenic hormone biosynthesis genes without interfering with its ability to integrate into plant chromosomes [1,2].

There are two types of disarmed tumor-inducing (Ti) plasmid vectors currently in use; these are co-integrative and binary vectors. The T-DNA and vir functions are maintained within the same Ti plasmid in co-integrative vectors. In contrast, binary vectors have the vir and TDNA regions on separate replicons. In this latter system, the T-DNA borders are located on a replicon that will function in both E. coli and Agrobacterium, a feature that greatly facilitates construct formation. Although the vir and T-DNA regions are in trans, the inserted DNA be-

\footnotetext{
*Corresponding author.
}

tween the T-DNA borders is efficiently transferred to the plant's genome [3].

pGV3850 is an example of a co-integrative vector [4]. Zambryski et al. [4] created a deletion mutant of pTiC58 where most of the DNA between the right and left border sequences of the T-DNA had been lost, including the genes for hormone production. The nopaline synthase gene remained and acts as a T-DNA specific marker. In addition, the cloning vector, pBR322, was inserted in the T-DNA region. The pBR322 sequence can act as an acceptor site for the insertion of genes to be transferred to the plant through a single recombination event with plasmids containing homologous sequences. Using this vector, Zambryski et al. [4] were able to transform plant tissues and regenerate fertile adult plants. Hoekema et al. [5] developed the binary vector strategy by creating the plasmid pAL1050. pAL1050 is a derivative of pTiAch5 that can replicate in both $E$. coli and A. tumefaciens and contains the T-DNA region. This plasmid was introduced into the cell line, LBA4404, which harbours the plasmid, pAL4404. This latter plasmid was isolated as a spontaneous deletion mutant of an octopine-type Ti plasmid that had lost its entire T-DNA but retained a complete complement of vir functions [6]. The combination of the two plasmids induced tumour formation on tomatoes, Kalanchoë, tobacco and peas despite the fact that the T-DNA and vir regions were on separate plasmids [5]. Since this time, several disarmed binary vector systems have been produced. 
Genetic transformation in a co-integrative system of avocado using Agrobacterium strain 9749 ASE2 with pMON9749 has been reported [7]. This study transformed embryonic cultures of 'Thomas' cultivar, but has failed to generate mature plantlets. There has been substantial gap between the uses of different methodology for potential genetic transformation systems for avocados were evident from the previous researches. It is also more or less clear that there has not consequently been enough research in Agrobacterium mediated transformation of avocado. Investigations were made to find: 1) which disarmed strains of Agrobacterium is most virulent on avocado cultivar "Hass"; and 2) what culture conditions give maximum transformation. Therefore, the main purposes of this study were to determine the conditions for successful transformation using disarmed vectors containing the $\beta$-glucuronidase (GUS) reporter gene.

\section{Materials and Methods}

\subsection{Triparental Mating}

Cultures of donor (E. coli strains containing pBI121 or pCGP904), recipient (A. tumefaciens strains AGL1, GV3850 and LBA4404), and helper (E. coli containing pRK2013) strains were grown overnight at $28^{\circ} \mathrm{C}$ in 10 $\mathrm{mL}$ of lysogeny broth (LB) containing the appropriate level of the relevant antibiotic. On the following day, the bacterial strains were streaked each onto LB agar containing kanamycin or rifampicin to test their antibiotic sensitivities: cell lines showing the appropriate antibiotic sensitivities were incubated again overnight at $28^{\circ} \mathrm{C}$. The overnight cultures were transferred to sterile $10 \mathrm{~mL}$ centrifuge tubes and the bacteria pelleted at $8000 \mathrm{rpm}$ for 5 minutes, then resuspended in $5 \mathrm{~mL}$ of fresh LB. The bacteria were then repelleted and resuspended as above. $1.0 \mathrm{~mL}$ aliquots of the donor strains were placed in $2.0 \mathrm{~mL}$ Eppendorf tubes and centrifuged for 5 minutes at 8000 rpm to pellet the bacteria after which the supernatants were removed. Next, $1.0 \mathrm{~mL}$ of the recipient strains was added to the suspended donor strains, which were then centrifuged for 5 minutes at 8000 rpm to pellet the bacteria and the supernatants again removed. Finally, $0.5 \mathrm{~mL}$ of the helper strain was added to each tube, the bacterial mixtures were then vortexed for 1 minute after which the bacteria were pelleted and then resuspended. The slurry was transferred to LB agar plates, which were incubated for 48 hours at $28^{\circ} \mathrm{C}$ for triparental matings to take place. After incubation, a scrape from each triparental mating was taken and added to a $2 \mathrm{~mL}$ Eppendorf tube containing $200 \mu \mathrm{L}$ of sterilized distilled water. The bacteria were resuspended by vortexing and the suspension used to make lawn culture on LB agar containing the appropriate antibiotics to select the desired transconjugant. The plates were incubated at $28^{\circ} \mathrm{C}$ and after 2 - 4 days bacte- rial colonies appeared. This process created the following combinations of bacterial strains and binary vector: AGL1/pCGP904; AGL1/pBI121; GV3850/pCGP904; GV3850/pBI121; LBA4404/pCGP904 and LBA4404/pBI121.

\subsection{Parameter Optimization for Maximum Transformation}

The binary vectors produced earlier were subjected to different $\mathrm{pH}$ levels and concentration of acetosyringone (AS). The strain of bacterium that gave maximum transformation of avocado tissues was recorded. The different disarmed strains of $A$. tumefaciens created in previous section were grown overnight in LB medium containing the appropriate antibiotics. Ten-fold dilutions of the cultures were made in sterile distilled water. Embryonic shoot axes of cultivar (cv.) "Hass" were cut transversely into sections of approximately $10 \mathrm{~mm}$ diameter, immersed in the diluted bacterial cultures for one minute and then blotted dry to remove excessive moisture. The shoot axes were placed on co-cultivation medium (Murashige and Skooge (MS) [8] salts, $30 \mathrm{~g} \cdot \mathrm{L}^{-1}$ sucrose, 1.0 $\mathrm{mg} \cdot \mathrm{L}^{-1}$ 6-benzyl amino purine (BAP), $0.1 \mathrm{mg} \cdot \mathrm{L}^{-1}$ IBA, $500 \mathrm{mg} \cdot \mathrm{L}^{-1} \mathrm{PVP}$, and $0.7 \%$ Bacto-agar) with the different concentrations of AS and pH levels (Table 1).

Five embryonic shoot axes were placed in each Petri dish. The plates were held at $24^{\circ} \mathrm{C} \pm 1^{\circ} \mathrm{C}$ for 48 hours to allow DNA transfer to occur. After two days, the embryonic shoot tissues were transferred to regeneration medium (4.4 g. $\mathrm{L}^{-1}$ modified MS salts supplemented with 30 $\mathrm{g} \cdot \mathrm{L}^{-1}$ sucrose, $1.0 \mathrm{mg} \cdot \mathrm{L}^{-1} \mathrm{BAP}, 0.1 \mathrm{mg} \cdot \mathrm{L}^{-1} \mathrm{IBA}, 10^{-4} \mathrm{M}$ putrescine, $500 \mathrm{mg} \cdot \mathrm{L}^{-1}$ cefotaxime, $0.7 \%$ Bacto-agar at $\mathrm{pH}$ 5.7). One week later, the explants were transferred from regeneration medium to the selection medium (2.3 $\mathrm{g} \cdot \mathrm{L}^{-1}$ woody plant medium (WPM) salts, $30 \mathrm{~g} \cdot \mathrm{L}^{-1} \mathrm{su}-$ crose, $0.1 \mathrm{mg} \cdot \mathrm{L}^{-1} \mathrm{BAP}, 1.0 \mathrm{mg} \cdot \mathrm{L}^{-1} \mathrm{IBA}, 10^{-4} \mathrm{M}$ putrescine, $500 \mathrm{mg} \cdot \mathrm{L}^{-1}$ cefotaxime, $60 \mathrm{mg} \cdot \mathrm{L}^{-1} \mathrm{kanamycin}$, $0.7 \%$ Bacto-agar at $\mathrm{pH}$ 5.7). The majority of explants

Table 1. Co-cultivation media with different concentrations of pH and acetosyringone.

\begin{tabular}{ccc}
\hline Treatment & $\mathrm{pH}$ & Acetosyringone \\
\hline i & 5.2 & - \\
ii & 5.2 & $200 \mu \mathrm{M}$ \\
iii & 5.2 & $400 \mu \mathrm{M}$ \\
iv & 5.7 & - \\
v & 5.7 & $200 \mu \mathrm{M}$ \\
vi & 5.7 & $400 \mu \mathrm{M}$ \\
vii & 6.2 & - \\
viii & 6.2 & $200 \mu \mathrm{M}$ \\
ix & 6.2 & $400 \mu \mathrm{M}$ \\
Control & 5.7 & - \\
\hline
\end{tabular}


were examined after one week (two weeks after co-cultivation) for activity of the GUS reporter gene [9]. In addition, a few shoot bases were examined 2 and 7 days after co-cultivation. Transformation rates were estimated by visual assessment using the scoring system in Table 2.

\subsection{Transformation with Agrobacterium strain GV3850/pBI121}

GV3850/pBI121 was grown to an $\mathrm{OD}_{580}$ of 0.7 - 1.0 at $27^{\circ} \mathrm{C} \pm 1^{\circ} \mathrm{C}$ in $\mathrm{LB}$ containing $50 \mathrm{mg} \cdot \mathrm{L}^{-1}$ rifampicin and $25 \mathrm{mg} \cdot \mathrm{L}^{-1}$ kanamycin. A ten-fold dilution of the overnight culture of the strain was made in sterile distilled water. $10 \mathrm{~mm}$ sections of embryonic shoot axes were immersed in the diluted bacterial culture for minute and blotted dry. The embryonic shoot axes were placed on co-cultivation medium with five sections per Petri dish. The plates were held at $24^{\circ} \mathrm{C} \pm 1^{\circ} \mathrm{C}$ for 48 hours to allow DNA transfer to occur. After two days, the embryonic shoot tissues were transferred to regeneration medium containing $60 \mathrm{mg} \cdot \mathrm{L}^{-1}$ kanamycin. One week later, the explants were further transferred to the selection medium in which kanamycin was omitted for four weeks. All putative transformed explants were again analysed for GUS reporter gene expression. Six shoots were taken for analysis by PCR to determine the present or absence of the GUS and virD genes within their genomes.

\subsection{Histochemical Assay of GUS Activity}

$5.22 \mathrm{mg}$ of X-gluc was dissolved into 1 - 2 drops of $\mathrm{N}$, $\mathrm{N}$-dimethylformamide and the solution made up to $10 \mathrm{~mL}$ using $0.2 \mathrm{M}$ phosphate buffer ( $\mathrm{pH}$ 7.0). Putative transformed explants were placed in Eppendorf tubes, covered with X-gluc solution for 24 hours at $20^{\circ} \mathrm{C}$ for the staining reaction to occur.

\subsection{DNA Extraction from Plant Tissue}

80 - $100 \mathrm{mg}$ tissue was taken from regenerating shoots (resulting from section 1.3) 6 - 8 weeks after co-cultivation and grounded using a pestle and mortar (previously kept in hot water bath at $65^{\circ} \mathrm{C}$ ) with $750 \mu \mathrm{L}$ of Extraction Buffer II (also preheated). Each individual sample was poured into a $2 \mathrm{~mL}$ Eppendorf tube containing $300 \mu \mathrm{L}$ chloroform and the mortars washed with $750 \mu \mathrm{L}$ of Extraction Buffer II which was also placed in the Eppendorf tubes. The Eppendorf tubes were inverted several times, incubated at $65^{\circ} \mathrm{C}$ for 30 minutes then microcentrifuged at $13,000 \mathrm{rpm}$ for 5 minutes. The supernatants were transferred to $2 \mathrm{~mL}$ Eppendorf tubes containing $600 \mu \mathrm{L}$ of cold isopropanol, inverted slowly several times until a precipitate formed, centrifuged at 13,000 rpm for 5 minutes and the supernatant removed. Each pellet was then washed twice with $500 \mu \mathrm{L}$ of $70 \%$ ethanol and once with $500 \mu \mathrm{L}$ of $100 \%$ ethanol after which the tubes were inverted to drain off the alcohol. The DNA samples were then vacuum dried for 15 minutes and stored at $4^{\circ} \mathrm{C}$.

\subsection{DNA Extraction from Bacteria}

Cultures of GV3850/pBI121 (5 mL) were grown overnight. $1.5 \mathrm{~mL}$ of the culture was placed in a $2.0 \mathrm{~mL}$ Eppendorf tubes and microcentifuged for 2 minutes. The bacterial pellets were resuspended in $567 \mu \mathrm{L}$ TE buffer by repeated pipetting following which $30 \mu \mathrm{L}$ of $10 \%$ SDS and $3 \mu \mathrm{L}$ of $20 \mathrm{mg} \cdot \mathrm{mL}^{-1}$ proteinase $\mathrm{K}$ were added, mixed and the sample incubated for $1 \mathrm{~h}$ at $37^{\circ} \mathrm{C}$. After incubation, $100 \mu \mathrm{L}$ of $5 \mathrm{M} \mathrm{NaCl}$ and $80 \mu \mathrm{L} \mathrm{CTAB} / \mathrm{NaCl}$ solution were added, mixed and the tubes then incubated for 10 minutes at $65^{\circ} \mathrm{C}$. To remove contaminating polysaccharides and other macromolecules, an equal volume (870 $\mu \mathrm{L})$ of chloroform/isoamyl alcohol (24:1) was added, the tubes shaken, then centrifuged for 5 minutes and the aqueous phase transferred to a fresh tube. An equal volume of phenol/chloroform/isoamyl alcohol (25:24:1) was added to the aqueous phase and the contents were thoroughly mixed. The tubes were then centrifuged and the aqueous phase transferred to a fresh $2 \mathrm{~mL}$ Eppendorf tube. A $0.6 \mathrm{ml}$ of isopropanol was then added, mixed gently and the precipitated DNA collected by microcentrifugation at 13,000 rpm for 2 minutes. The supernatant was then removed and the DNA pellets washed twice with $500 \mu \mathrm{L}$ of $70 \%$ ethanol and once with $500 \mu \mathrm{L}$ of $100 \%$ ethanol. The bacterial DNA samples were vacuum dried for 15 minutes and stored at $4^{\circ} \mathrm{C}$.

\subsection{PCR Analysis}

A multiplex PCR assay was conducted for detection of the GUS and virD1 genes using specific primers (Table 3). The reaction mixture for PCR consisted of the following reagents: $2.5 \mathrm{mM} \mathrm{MgCl}_{2}, 1 \mathrm{X}$ manufacturer's Taq buffer, $1 \mathrm{U}$ Taq polymerase, $200 \mu \mathrm{M}$ dNTPs, $1 \mu \mathrm{M}$ of each primer, 50 ng target DNA, and $\mathrm{dH}_{2} \mathrm{O}$ to make a total

Table 2. Primers sequence for amplification of vir and gus genes.

\begin{tabular}{cccc}
\hline Gene & Primer Sequence & Amplicon size (bp) & Reference \\
\hline Vir-D1-1 & 5' ATGTCGCAAGGCAGTAAGCCCA 3' & 437 & {$[10]$} \\
Vir-D1-2 & 5' GGAGTCTTTCAGCATGGAGCAA 3' & & \\
GUS_GI & 5' GGTGGGAAAGCGCGTTACAAG 3' & 1199 & {$[9]$} \\
GUS_GII & 5' GTTTACGCGTTGCTTCCGCCA 3' & & \\
\hline
\end{tabular}


Table 3. Extent of transformation of avocado tissues (cv. "Hass”) two weeks after co-cultivation with six combinations of cell line and binary vector after co-cultivation on media containing different concentrations of acetosyringone and at different $\mathrm{pH}$ levels. (Scoring system: - = no blue cells present; + = a few blue cells present; ++ = small areas of blue tissue present; $+++=$ large areas of blue tissue present).

\begin{tabular}{|c|c|c|c|c|c|c|}
\hline Treatments & $\begin{array}{c}\text { AGL1 } \\
\text { /pBI121 }\end{array}$ & $\begin{array}{c}\text { AGL1 } \\
\text { /pCGP904 }\end{array}$ & $\begin{array}{l}\text { GV3850 } \\
\text { /pBI121 } \\
\end{array}$ & $\begin{array}{l}\text { GV3850 } \\
\text { /pCGP904 }\end{array}$ & $\begin{array}{c}\text { LBA4404 } \\
\text { /pBI121 }\end{array}$ & $\begin{array}{l}\text { LBA4404 } \\
\text { /pCGP904 } \\
\end{array}$ \\
\hline $\begin{array}{c}\mathrm{pH} \text { 5.2, } \\
\text { no acetosyringone }\end{array}$ & - & - & + & + & + & + \\
\hline $\begin{array}{l}\mathrm{pH} \text { 5.2, } 200 \mu \mathrm{M} \\
\text { acetosyringone }\end{array}$ & + & + & +++ & ++ & + & ++ \\
\hline $\begin{array}{l}\mathrm{pH} 5.2,400 \mu \mathrm{M} \\
\text { acetosyringone }\end{array}$ & + & + & + & + & + & + \\
\hline $\begin{array}{c}\mathrm{pH} 5.7, \\
\text { no acetosyringone }\end{array}$ & - & - & + & - & - & - \\
\hline $\begin{array}{l}\text { pH } 5.7200 \mu \mathrm{M} \\
\text { acetosyringone }\end{array}$ & + & + & ++ & + & + & + \\
\hline $\begin{array}{l}\mathrm{pH} 5.7,400 \mu \mathrm{M} \\
\text { acetosyringone }\end{array}$ & + & + & + & + & + & + \\
\hline $\begin{array}{c}\text { pH 6.2, } \\
\text { no acetosyringone }\end{array}$ & - & - & + & + & - & - \\
\hline $\begin{array}{l}\mathrm{pH} 6.2,200 \mu \mathrm{M} \\
\text { acetosyringone }\end{array}$ & + & + & ++ & + & + & + \\
\hline $\begin{array}{l}\mathrm{pH} 6.2,400 \mu \mathrm{M} \\
\text { acetosyringone }\end{array}$ & + & + & + & + & + & + \\
\hline $\begin{array}{l}\text { Control, non-transformed } \\
\text { tissue }\end{array}$ & - & - & - & - & - & - \\
\hline
\end{tabular}

of $25.0 \mu \mathrm{L}$.

To six tubes, DNA from different putative transformed avocado plants was added. To another tube, DNA from a non-transformed plant was added, to another $50 \mathrm{ng}$ of bacterial DNA and to the final tube, sterilized distilled water was added. The samples were vortexed, the tubes centrifuged for 10 seconds then the contents were overlayered with $40 \mu \mathrm{L}$ of mineral oil. Cycling parameters for amplification were an initial cycle of denaturation at $93^{\circ} \mathrm{C}$ for 5 mins, followed by 40 cycles at $93^{\circ} \mathrm{C}$ for $30 \mathrm{~s}$, annealing at $60^{\circ} \mathrm{C}$ for $1 \mathrm{~min}$, extension at $72^{\circ} \mathrm{C}$ for $2 \mathrm{~min}$.

PCR products of each reaction mixture were added to gel loading buffer and loaded onto a $1 \%$ agarose gel. The fragments were subjected to electrophoresis at 90 volts per centimetre for 60 minutes in 1× TBE buffer. The gel was stained with ethidium bromide and visualised using a transilluminator with a wavelength of $320 \mathrm{~nm}$.

\section{Results and Discussion}

In this study, six strains of Agrobacterium tumefaciens, namely AGL1/pBI121; AGL1/pCGP904; GV3850/pBI121; GV3850/pCGP904; LBA4404/pBI121 and LBA4404/pCGP904 were studied for genetic transformation of avocado. Expressions of the GUS reporter gene in embryonic shoot axes were assessed by staining with $\mathrm{X}$-gluc. The histochemical assay revealed GUS activity in most of the explants treated with disarmed strains of $A$. tumefaciens. Among the three different cell lines, trans- formation with the disarmed binary vector GV3850 was found most effective (Figure 1 and Table 3). Transformation rates using LBA4404 and AGL1 were lower than GV3850 and there appears to be no differences between LBA4404 and AGL1 in their ability to cause transformation. $200 \mu \mathrm{M}$ acetosyringone increased transformation rates; however, transformation rates were reduced when the level of acetosyringone was increased to $400 \mu \mathrm{M}$. Among the media with different $\mathrm{pH}$ levels, a $\mathrm{pH}$ of 5.2 allowed more transformation than $\mathrm{pH} 5.7$ and 6.2. The construct, pBI121 produced more blue cells than pCGP904. The control (non-infected tissue) did not show any GUS activity. GUS activity was first observed around the cut edges of the tissues after two days after co-cultivation. The amount of GUS positive cells and sectors decreased with time.

The presence of the GUS gene in explants expressing GUS activity was confirmed by PCR (Figure 2). Lane 9 shows the two PCR products, amplified from bacterial DNA, that correspond to the GUS gene (fragment size 1199bp) and the virD1 gene (fragment size $437 \mathrm{bp}$ ). Lanes 3 and 8 contained PCR products from putative transformed avocado plants and in these lanes only the fragment corresponding to the GUS gene is present. Extracts from the remainder of the putative transformants (lanes 4 - 7) and the non-transformed control (lane 2) failed to produce DNA amplification products.

Studies of co-cultivation conditions with disarmed 


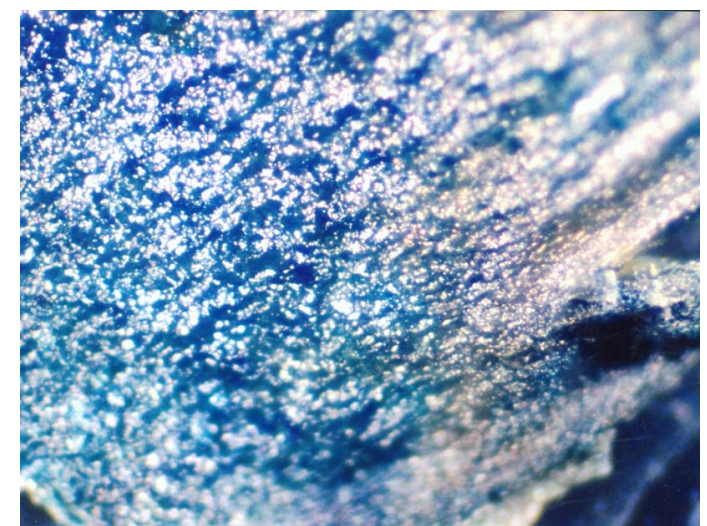

Figure 1. Histochemical analysis of GUS gene expression in transgenic avocado tissues transformed using the disarmed Agrobacterium tumefaciens strain, GV3850/pBI121.

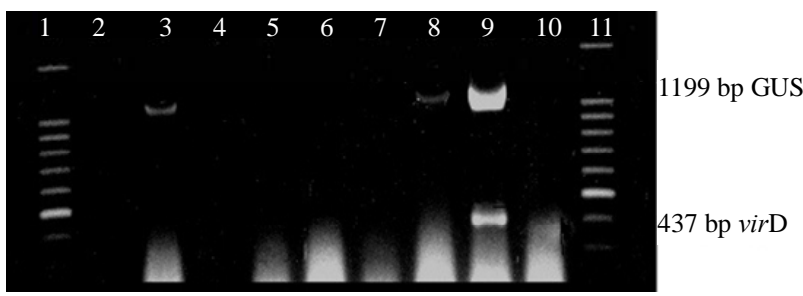

Figure 2. Separation of PCR products following PCR amplification using primers designed from the virD and GUS genes. Lanes 1 and 11 contain 100 base pair ladder; lane 10 contains the water control (no template DNA); lane 9 contains PCR products from bacterial DNA; lanes 3 to 8 contains PCR products from putative transformed avocado plants and lane 2 contains the PCR products from the negative control (template DNA from a non-transformed avocado plant). The expected PCR products of the virD and GUS genes are fragments with a length of 437 and 1199bp, respectively.

strains of Agrobacterium have confirmed the results obtained with wild-type strains in this study. Maximum transformation rates were again obtained when the medium contained $200 \mu \mathrm{M}$ acetosyringone and had a $\mathrm{pH}$ of 5.2. Surprisingly, increasing the concentration of acetosyringone to $400 \mu \mathrm{M}$ reduced transformation levels. The reason for this is not clear but may be related to toxic effects of acetosyringone on plant tissues. Acetosyringone at a concentration of $200 \mu \mathrm{M}$ prevented the germination of seeds of Antirrhinum majus (Holford, pers comm.) and the $400 \mu \mathrm{M}$ level used in this study may be affecting the growth or development of certain avocado cells.

In this study, different host cell lines of Agrobacterium were used; AGL1, GV3850, and LBA4404, and induced different levels of transformation. Specifically, GV3850 was found to be the most effective in producing the transgenic tissues. Other studies have found differences in the virulence of different strains of Agrobacterium. For example, Berres et al. [11] also found transformation with LBA4404/pAL4404/pBI121.2 was inefficient on grapevines. Lulsdorf et al. [12] used the binary vector, pBI1042, for experiments on the transformation of pea. This vector was placed in three different strains (EHA101, LBA4404 and WR3095). The use of EHA101 significantly increased the number of transformation events and these authors suggested that this must be due to factors associated with the bacterial chromosome.

Ranges of chromosomal genes are involved in the interaction between Agrobacterium and its host. The att locus contains the genes required for successful bacterial attachment to plant cells [13] and has been extensively studied [14]. Genes located on one part of the locus are thought to be responsible for the synthesis of fundamental binding components. Other genes are involved in molecular signaling events and show homology to genes involved in periplasmic binding protein dependent transport systems $[15,16]$. The ABC transporter encoding genes of the att region may be involved in the secretion of substances or in the introduction into bacteria of some plant-originated activators of the synthesis of compounds specific for attachment [17]. Differences in the expression of these types of genes between different strains of Agrobacterium are capable of explaining differences in virulence seen in this study.

More blue cells were visible when the explants were treated with pBI121 than the pCGP904. The latter plasmid contains the GUS cassette (mas35S: GUS: ocs3') from pKIWI101 inserted into pBIN19 [18]. The GUS gene in pCGP904 contains a hybrid promoter incorporating elements from both CaMV 35S and Ti plasmid mannopine synthetase (MAS) [19]. This promoter, called Mac, expressed GUS at a level 3 to 5 times that expressed by a double $35 \mathrm{~S}$ promoter in the leaves, and 10 to 15 times that in hypocotyls and roots. The Mac promoter, however, showed only marginal wound inducibility. The difference between levels of GUS activity seen between avocado tissues transformed pBI121 or pCGP904 may be due differences in the induction of the GUS gene due to stresses induced by co-cultivation, the tissue culture environment or the staining process.

Decreased of GUS positive sectors were observed in transformed avocado tissues overtime. This phenomenon has been observed in other studies. For example, Orlikowska et al. [20] showed that the number of transformed sectors, visible in safflower treated with either pBI121 or EHA105 two weeks after co-cultivation, decreased between half to one third of the levels seen after three days. These authors explained the decline as being due to a reduction of transient expression over time.

In this study, DNA from two out of the six avocado explants acted as a template for the amplification of a band with the expected size of the GUS gene. The use of PCR to detect sequences in transformed plants has been 
questioned because of the possibility that cells or DNA from Agrobacterium may remain on the surface of plant tissues long after co-cultivation has occurred. To ensure that only DNA incorporated into the plants' genomes was the template for amplification, PCR was also attempted using primers designed from the virD1 gene. As the virD1 gene is in the virulence region of the Ti plasmid and is outside of the T-DNA borders it cannot be transferred to the plant. The presence of a virD1 and GUS bands in PCR amplifications using extracts from plant tissues would indicate the presence of contamination by Agrobacterium or its DNA: the presence of only the GUS band indicates stable transformation. This system has been used to demonstrate transformation of $\mathrm{An}$ tirrhinum majus [21]. None of the amplifications using extracts from putative transgenic plants produced DNA fragments of the expected size of the virD1 sequence. Therefore, the amplification of the GUS gene must have been its stable incorporation in the plants. Both the virD1 and GUS genes were readily amplified from bacterial extracts. Moreover, this study has shown that Agrobacterium strain, GV3850, is the most suitable and an efficient vector for the transformation study of avocado. Further research is required using the latter strain to assess its efficiency and reliability of gene transfer for biotic and abiotic stresses.

\section{REFERENCES}

[1] R. B. Horsch, J. Fry, N. Hoffmann, J. Neidermeyer, S. G. Rogers and R. T. Fraley, "Leaf Disc Transformation," In: S. B. Gelvin, R. A. Schilperoort and D. P. Verma, Eds., Plant Molecular Biology Manual, Kluwer Academic Publisher, Belgium, 1988, pp. 1-9.

[2] H. Klee and S. Rogers, "Plant Gene Vectors and Genetic Transformation: Plant Transformation System Based on the Use of Agrobacterium tumefaciens," In: J. Schell and I. K. Vasil, Eds., Cell Culture and Somatic Cell Genetics of Plants, Vol. 6: Molecular Biology of Plant Nuclear Genes, Academic Press, London, 1989, pp. 1-23.

[3] G. An, P. R. Ebert, A. Mitra and S. Ha, "Binary Vectors," In: S. B. Gelvin, R. A. Schilperoort and D. P. Verma, Eds., Plant Molecular Biology Manual, Kluwer Academic Publisher, Belgium, 1988, pp. 1-19.

[4] P. Zambryski, H. Joos, C. Genetello, J. Leemans, M. Van Montagu and J. Schell, "Ti-Plasmid Vector for the Introduction of DNA into Plant Cells without Alteration of Their Normal Regeneration Capacity,” EMBO Journal, Vol. 12, No. 2, 1983, pp. 2143-2150.

[5] A. Hoekema, P. R. Hirsch, P. J. J. Hookaas, and R. A. Schilperoot, "A Binary Plant Vector Strategy Based on Separation of vir- and T-Region of the Agrobacterium tumefaciens Ti Plasmid,” Nature, Vol. 303, 1983, pp. 179180. doi:10.1038/303179a0

[6] G. Ooms, P. Hooykaas, G. Moolenaar, and R. Schilperoort, "Crown Gall Tumors of Abnormal Morphology Induced by Agrobacterium tumefaciens Carrying Mutated
Octopine Ti Plasmids; Analysis of T-DNA Functions,” Gene, Vol. 14, No. 1-2, 1981, pp. 33-50.

doi:10.1016/0378-1119(81)90146-3

[7] A. Cruz-Hernández, Witjaksono, R. E. Litz and M. Gomez Lim, “Agrobacterium tumefaciens-Mediated Transformation of Embryogenic Avocado Cultures and Regeneration of Somatic Embryos,” Plant Cell Reports, Vol. 17, No. 6-7, 1998, pp. 497-503. doi:10.1007/s002990050431

[8] T. Murashige and F. Skoog, "A Revised Medium for Rapid Growth and Bio Assays with Tobacco Tissue Cultures,” Physiologia Plantarum, Vol. 15, No. 3, 1962, pp. 473-497. doi:10.1111/j.1399-3054.1962.tb08052.x

[9] R. A. Jefferson, T. A. Kavanagh, and M. W. Bevan, "GUS Fusions: $\beta$-Glucuronidase as a Sensitive and Versatile Gene Fusion Marker in Higher Plants,” EMBO Journal, Vol. 6, No. 13, 1987, pp. 3901-3907.

[10] K. H. Lipp Joao and T. A. Brown, "Enhanced Transformation of Tomato Co-Cultivated with Agrobacterium tumefaciens C58CIRif::pGSFR1161 in the Presence of Acetosyringone,” Plant Cell Reports, Vol. 12, No. 7-8, 1993, pp. 422-425. doi:10.1007/BF00234705

[11] R. Berres, L. Otten, B. Tinland, E. Clog and B. Walter, "Transformation of Vitis Tissue by Different Strains of Agrobacterium tumefaciens Containing the T-6b Gene," Plant Cell Reports, Vol. 11, No. 4, 1992, pp. 192-195. doi:10.1007/BF00232531

[12] M. M. Lulsdorf, H. Rempel, J. A. Jackson, D. S. Baliski and S. L. A. Hobbs, "Optimizing the Production of Transformed Pea (Pisum sativum L.) Callus Using Disarmed Agrobacterium tumefaciens Strains,” Plant Cell Reports, Vol. 9, No. 9, 1991, pp. 479-483. doi:10.1007/BF00232100

[13] G. A. De la Riva, G. C. Joel, R. Vázquez-Padrón and C. Ayra-Pardo, "Agrobacterium tumefaciens: A Natural Tool for Plant Transformation," Electronic Journal of Biotechnology, Vol. 1 No. 3, 1998. doi:10.2225/vol1-issue3-fulltext-1

[14] L. R. Bradley, J. S. Kim and A. G. Matthysse, "Attachment of Agrobacterium tumefaciens to Carrot Cells and Arabidopsis Wound Sites Is Correlated with the Presence of a Cell-Associated, Acidic Polysaccharide,” Journal of Bacteriology, Vol. 179, No. 17, 1997, pp. 5372-5379.

[15] G. F. L. Ames, C. S. Mimura and V. Shyamala, "Bacterial Periplasmic Permeases Belong to a Family of Transport Proteins Operating from Escherichia coli to Human: Traffic ATPases,” FEMs Microbiological Review, Vol. 75, No. 4, 1990, pp. 429-446. doi:10.1016/0378-1097(90)90691-I

[16] C. F. Higgings, S. C. Hyde, M. M. Mimmack, U. Gileadi, D. R. Gill and M. P. Gallagher, "Binding Protein-Dependent Transport Systems,” Journal of Bioenergy and Biomembranes, Vol. 22, 1990, pp. 571-592. doi:10.1007/BF00762962

[17] A. G. Matthysse, H. A. Yarnall and N. Young, "Requirement for Genes with Homology to ABC Transport System for Attachment and Virulence of Agrobacterium tumefaciens," Journal of Bacteriology, Vol. 178, 1996, pp. 5302-5308. 
[18] M. Bevan, "Binary Agrobacterium Vectors for Plant Transformation," Nucleic Acids Research, Vol. 12, No. 22, 1984, pp. 8711-8721. doi:10.1093/nar/12.22.8711

[19] L. Comai, P. Moran and D. Maslyar, "Novel and Useful Properties of a Chimeric Plant Promoter Combining CaMV $35 S$ and MAS Elements," Plant Molecular Biology, Vol. 15, No. 3, 1990, pp. 373-381. doi:10.1007/BF00019155

[20] T. K. Orlikowska, H. J. Cranston and W. E. Dyer, "Fac- tors Influencing Agrobacterium tumefaciens-Mediated Transformation and Regeneration of the Safflower Cultivar 'Centennial'," Plant Cell, Tissue and Organ Culture, Vol. 40, 1995, pp. 85-91. doi:10.1007/BF00041122

[21] I. Senior, P. Holford, R. N. Cooley and H. J. Newbury, "Transformation of Antirrhinum majus Using Agrobacterium rhizogenese," Journal of Experimental Botany, Vol. 46, No. 9, 1995, pp. 1233-1239.

doi:10.1093/jxb/46.9.1233 